\title{
Hepatocelulární karcinom prorůstající do pravé srdeční síně
}

\author{
Martin Mašek, Manuela Vaněčková
}

Radiodiagnostická klinika, Všeobecná fakultní nemocnice a 1. lékařská fakulta Univerzity Karlovy, Praha, Česká republika

Pacient ve věku 63 let se známou jaterní cirhózou byl hospitalizován pro progredující otoky a ascites. $\mathrm{V}$ rámci vyšetřování bylo provedeno rovněž echokardiografické vyšetření, při kterém byl nalezen objemný útvar vyplňující pravou sín a vycházející z jaterního parenchymu. Následně bylo provedeno CT vyšetření hrudníku a břicha. CT prokázalo kromě masivního ascitu v dutině břišní patologický ložiskový proces jater. V konvexitě pravého jaterního laloku se zobrazila tumorózní masa o průměru $75 \mathrm{~mm}$, vzhledem ke známé cirhóze bylo vysloveno podezření na hepatocelulární karcinom. Tumorózní masa z jaterního parenchymu dále per continuitatem pokračovala jaterními žilami, podmiňovala perfuzní poruchu jaterního parenchymu a dále pokračovala až do pravé srdeční síně. Obraz byl interpretován jako obliterace jaterních žil na podkladě prorůstajícího tumoru, eventuálně kombi- nace prorůstajícího tumoru a nasedajícího trombu. CT angiografie a. pulmonalis dále prokázala oboustrannou plicní embolii se suspektně tumorózními tromby obturujícími větvení plicnice na úrovni lobárního, segmentárního a subsegmentárního větvení.

Kvůli posthepatální plicní hypertenzi s koagulopatií a kvůli rozsahu tumoru byl pacient indikován pouze k paliativnímu postupu, po několika dnech hospitalizace zemřel.

Sekce potvrdila závěr CT vyšetření:

1. hepatocelulární karcinom, jaterní cirhóza;

2. rozbředlé nádorové hmoty $\mathrm{v}$ jaterních žilách, prostupující až do dolní duté žíly, volné nádorové hmoty v pravé srdeční síni;

3. plicní embolie trombotická i tumorózní ad aa. pulmonales;

4. pleurální výpotek, ascites.

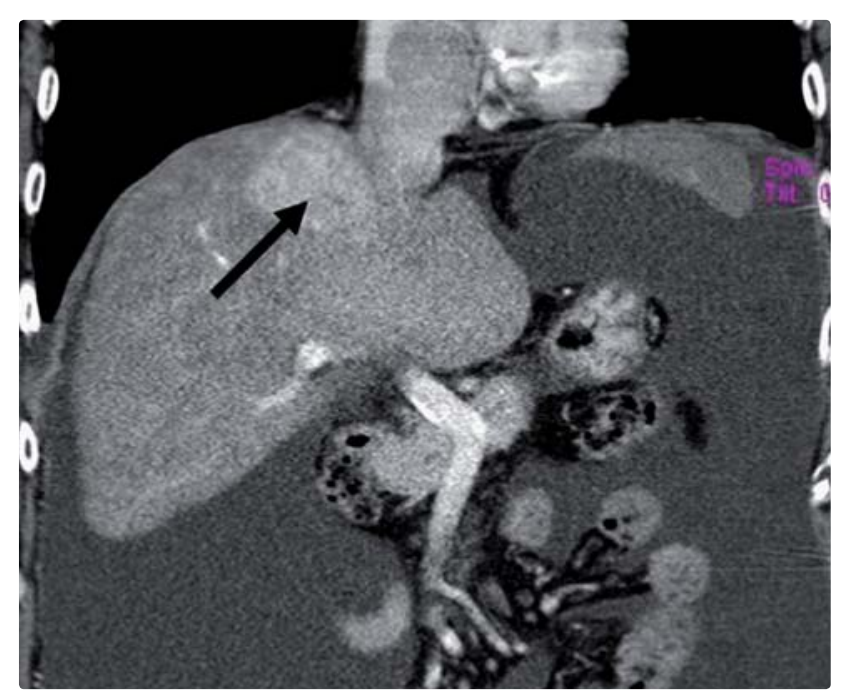

Obrázek 1 Hepatocelulární karcinom (šipka), ascites (CT vyšetření, koronární řez)

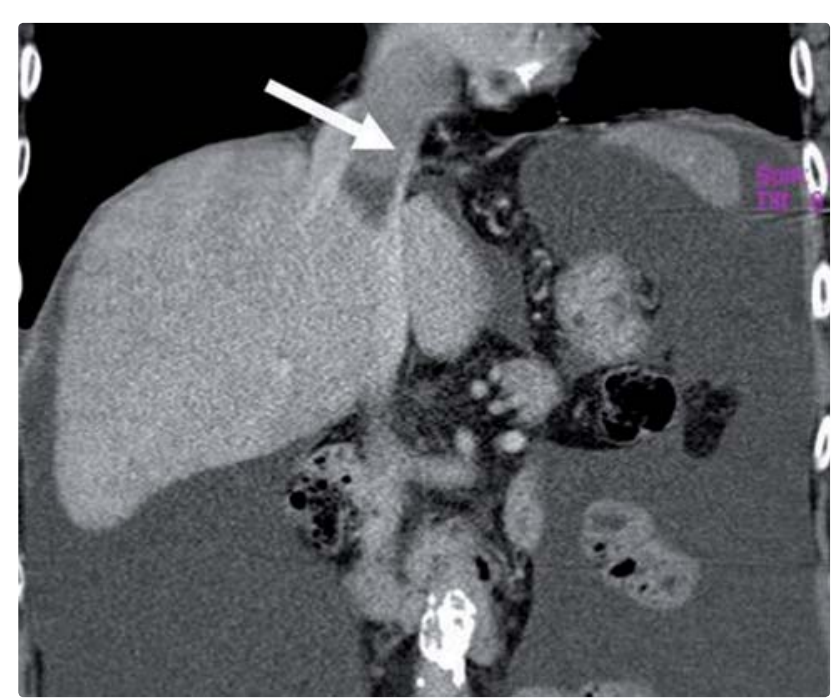

Obrázek 2 Nádorový trombus v dolní duté žíle (šipka), zasahující do pravé srdeční síně (CT vyšetření, koronární řez)

Adresa: MUDr. Martin Mašek, Ph.D., Radiodiagnostická klinika, VFN a 1. LF UK, U Nemocnice 2, 12808 Praha 2, Česká republika, e-mail: martinmasek@centrum.cz 

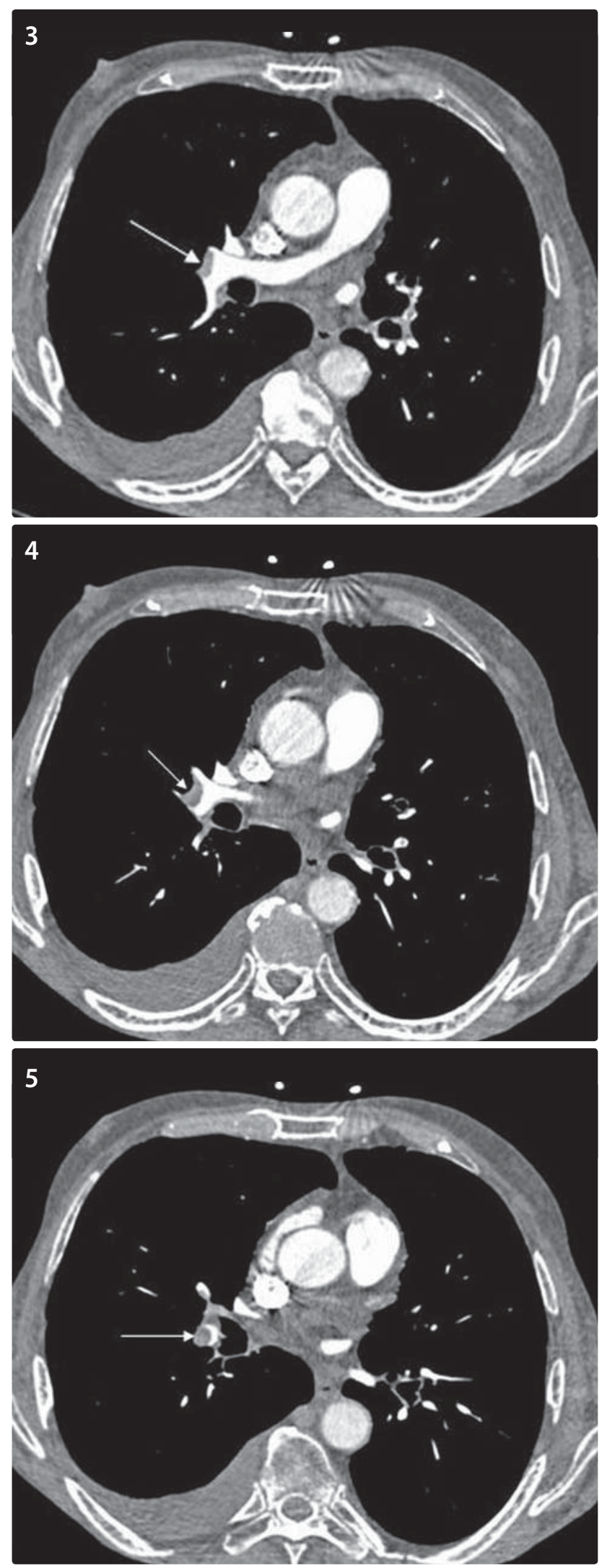

Obrázek 3-5 Embolizace do plicního řečiště (šipky), pleurální výpotek vpravo (CT angiografie, transverzální řezy)
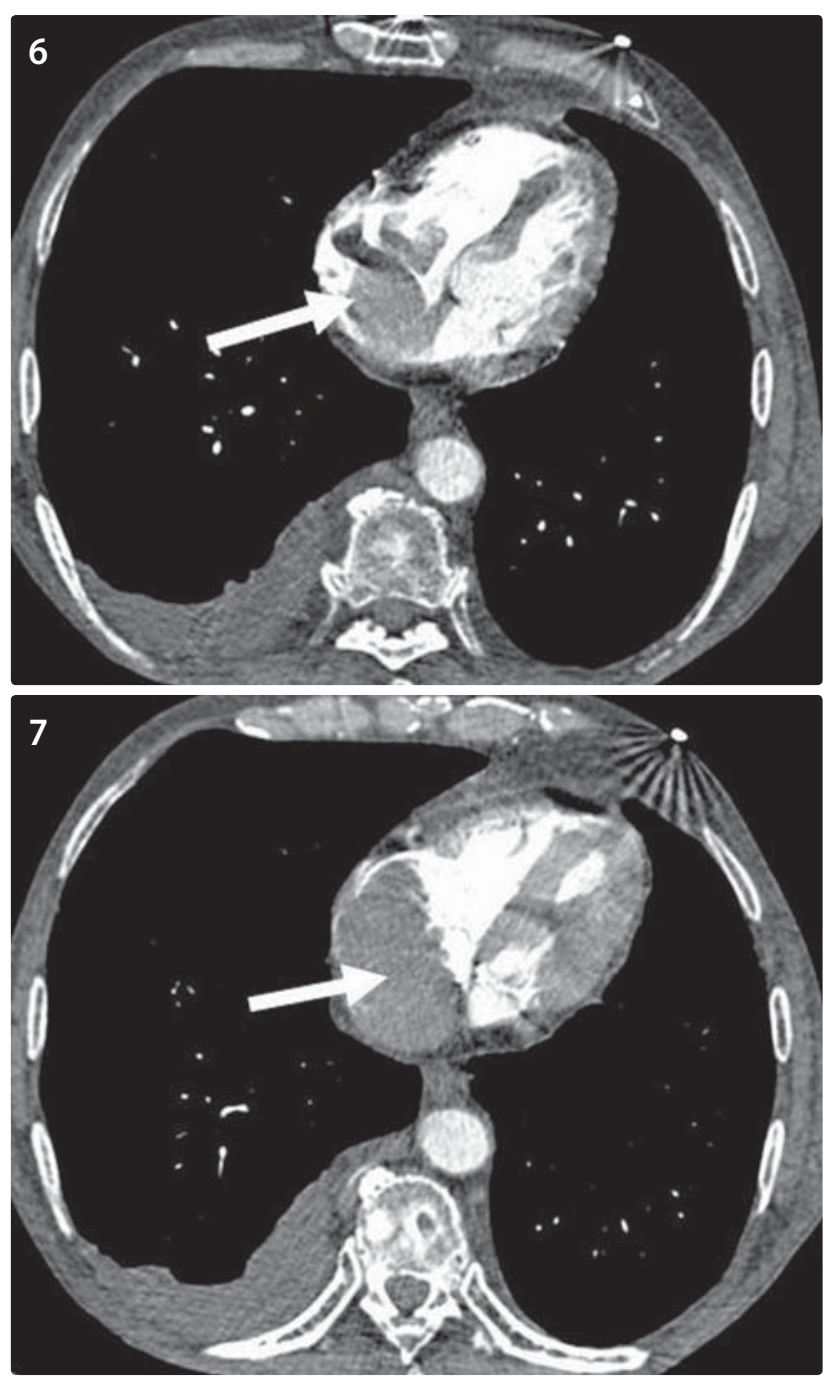

Obrázek 6,7 Tumorózní masa (šipka) v pravé srdeční síni (CT angiografie, transverzální řez)

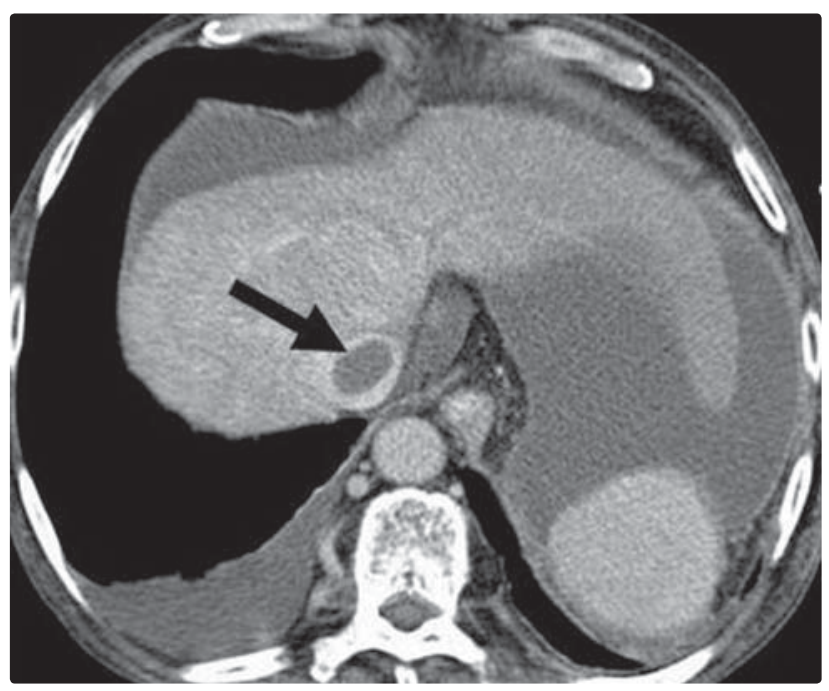

Obrázek 8 Nádorový trombus (šipka) v dolní duté žíle (CT vyšetření, transverzální řez) 